\title{
SME Finance and Economic Development Paradox: The Case of Fish Industry in The Gambia
}

\author{
Seeku A. K. Jaabi
}

\begin{abstract}
While the literature on enterprise finance focuses largely on manufacturing industry and in developing countries concerns enterprises in clustering industry, this study attempts to fill the gap by examining enterprise financing experiences in the fishing industry of The Gambia. Despite SMEs as spring board of industrialisation and development in most developing countries, they continue to face acute formal financial constraints. It is argued that the controversy in the empirical literature on the financing decisions on SMEs is based on the failure to take into account the degrees of information opacity, enterprises' capabilities and needs at specific stages of their life cycles. Fish as an agricultural commodity is perishable requiring capabilities and institutional developments to maintain freshness, and quality standards to boost production, processing and exports to lucrative markets and these require considerable financing requirements. The study adopted a mix approach using qualitative questionnaire survey and quantitative approach to assess the source and challenges of fish SME financing. The findings revealed that fish enterprises' access to formal financial credit is limited to supporting its production, processing and exports in The Gambia. The developmental role of government, innovative lending technologies of financial intermediaries and leasing firms can be instrumental in addressing the SMEs' persistent financing difficulties to enhance overall socio-economic developments. This makes fish SME financing study unique and complex in enterprise financing literature.
\end{abstract}

Key Words: Finance, Enterprise, Capital, Gambia

\section{INTRODUCTION}

The importance of SME financing in the economies of developing countries has been extensively researched in development economics literature (Berger \& Udell, 1998, 2006, Beck et al., 2006, Demirguc-kunt, 2007, Stiglitz \& Weiss, 1981), though very little if any on the experiences of low-income economies. SMEs and fish SMEs in particular contributes immensely to socio-economic development in terms of job creation, income for fishermen, foreign exchange through exports and provision of animal proteins to vast people who depend on it for livelihood support. Despite SMEs importance as a spring board of industrialisation and development in developing economies, it is paradoxical that they continue to face acute formal financial constraints.

The importance attached to fish SMEs in the economy is crucial making their access to formal external credit and equity vital for growth. This is corroborated by Storey (1994) that enterprise growth is constrained by cost of funding, availability and access to financial credit as investment is important for SMEs' viability and sustainability. SMEs capital structure financing differ from the large corporate bodies resulting to varying financing decisions and behaviours. 
Several important distinguishing factors between small from large businesses ${ }^{1}$ is linked to informational opacity(Berger and Udell, 1998, 2006). Information asymmetries do affect small firms' formal access to external debt and equity finance. As a result, the lack of access to external finance may not be due to the low demand for it but the difficulties of accessing it (Djankov et al 2007; Fafchamps, 1995 and Bigsten 2003). Accordingly, SMEs effective demand for formal finance depends on their ability to resolve asymmetric information (Beck et al. 20022; Rocca et al, 2011; Stiglitz and Weiss, 1981).

After financial reforms in most developing countries, SME financing attracted much attention due to their vital role in boosting socio-economic and industrial development in both developed and developing economies (Djankov, 2007, Fafchamps et al., 1995; Beck et al., 2006; Biggs 2006). However, despite its developmental role, fish SMEs continue to experience acute lack of access to formal finance due to various inherent internal and external constraints. Thus, in spite of the high risk profile, exposure to asymmetric information, lack of collateralised assets and informality that characterise most fish SMEs, policymakers and banks must formulate appropriate strategies to finance the needs of this important industry. Fish SMEs in The Gambia have access to a wide range of financing avenues including personal, family and friends, trade credit, microfinance, savings and credit cooperatives, government credit schemes and a more formal commercial bank financing.

Fish SMEs' importance in the economy depends to a greater extent on their unrestricted access to external finance. To understand fish SMEs' financing determinants at different stages of business life cycle can be crucial for financial intermediaries to appropriately support their financing needs. Fish SMEs lending decision-making has to take into account enterprises' characteristics, information opacity and their specific needs along the different stages of their life cycle, (Rogers et al, 2009:231; Fulgencio, 2009:434). SMEs acute lack of formal credit has resulted to the emergence of Non-governmental organisations (NGOs) and other informal financing to fill the gap by addressing difficulties in financial access. However, several studies including Ledgerwood (2000), Robinson (2001), Rhyne and White (2003) and Hulme and Mosley $(1996,1998)$ highlighted their serious limitations in addressing the long-term fish SME sustainable financing due to high donor dependence, limited funding capacity, weak management information systems and other corporate governance issues. These funding sources are not significant enough to support business expansion and growth potentials of fish SMEs. In this regard, governments in most developing economies have in the past assumed direct responsibility to extend financial credit to key sectors of the economy. They have therefore been in the forefront of promoting carefully crafted financial access in terms of direct allocation of funds to micro, small and medium-sized enterprises (SMEs) and the agricultural sector under various institutional arrangements (Jaabi, 2004). However, some of these interventions were short-lived due mainly to high non-performing loans, political hijacking, limited outreach and considerable losses. In most cases, the targeted people never received the funds.

Fish is a perishable commodity requiring technological capabilities and institutional building to enhance quality and hygiene fish handling along supply chains to boost production, processing and exports to lucrative markets. Fish industry is faced with stringent technical

\footnotetext{
${ }^{1}$ Large businesses use various financing options including stock markets, while small enterprises use external loans and owner's equity or support from family and friends. Small enterprises do not participate in stock markets due to high costs and too much formality.

${ }^{2}$ Beck, Demirguc-Kunt, and Maksimovic (2002) found that small businesses are severely credit constrained under weak local financial sector.
} 
barriers and strict sanitary standards requiring huge financial investment, skilled human resources, state-of-the-earth equipments and other capabilities to participate and compete in global markets where sophistication of products matter. This makes fish SME financing study unique and complex in enterprise financing literature quite different from SMEs in other industries requiring public policy support, in building the right systemic pillars to address collective action problems. Literature on enterprise financing largely focus on manufacturing industry and in developing countries concerns enterprises in clustering industry. This paper attempts to fill the gap by examining enterprise financing experiences in the fishing industry of The Gambia.

The continued lack of access to formal credit from commercial banks has been identified as a major constraint to enterprise operations and growth prospects (Becks et al., 2006; Storey, 1994; Berger and Udell, 1998, 2006). While empirical on enterprise financing focused largely on manufacturing and clustering industries in developing economies, this study examines the source of finance of fish SMEs and analyses its impact on fish exports and R\&D in Uganda's fish industry. What are the main financing sources and challenges of fish SMEs and its impact on exports in The Gambia's fishery industry? The latter form the research questions of the study. The paper begins with introduction and tracing the background of The Gambia fishery industry followed by a detailed literature review on the subject. This section also discusses the methodology and analytical approach adopted followed by the findings of the study. The paper concludes with a review of important findings and implications for the industry.

\section{BRIEF BACKGROUND OF THE GAMBIA'S FISH INDUSTRY}

The fisheries waters of The Gambia are characterised by marine Atlantic Ocean and an in-land fresh water of the River Gambia. It has territorial sea extending to 12 miles with an Exclusive Economic Zone (EEZ) of 200 miles long and 40 miles wide from the geographical baseline (Department of Fisheries, 2010). The continental shelf area of The Gambia is approximately 4000 square kilometres and an EEZ of nearly 10,500 square kilometres.

The River Gambia is an estuary with its source in the Fouta Djallon highlands in the Republic of Guinea Conakry, has a total length and its tributaries of $2,500 \mathrm{~km}$ and the river"s length in The Gambia is $480 \mathrm{~km}$ (Department of fisheries, 2011:2). In The Gambia, over 200,000 people depend on fish for livelihood support and employing over 40,000 people in the industry in 2009 (FAO, 2010; Department of Fisheries, 2009). Fish remains a vital source of animal protein in the country.

The sea corridor has over 500 marine fish species in demersal and pelagic in Gambian waters and about 70 fish species of commercial significance (Department of Fisheries, 2009). The fish resources are estimated to range from 300,000-350,000 metric tons (Mendy, 2009:3) with shrimps, catfish, cephalopods, cuttlefish, tilapia and tuna species making up the fish export basket. The fish resources of The Gambia are under-exploited and improvements in fishing technology and techniques, fish landings and exports are expected to increase into many folds. Commercial fishing started in early 1960s in The Gambia with both foreign and artisanal fisheries accessing coastal marine waters and inland river resources. The declaration of EEZs in 1982 law of the Sea enabled most West African coastal states including The Gambia to enter into fishing agreements with foreign countries - EU, South Korea, China, Greece, Spain, Italy, among others. This resulted to an intensive exploitation of fisheries resources through joint venture with local entrepreneurs. The commercialisation of fisheries products encouraged players to seize new opportunities by investing in modern fleets and processing plants in response to the growing global demand for fish and fish products. The fishing fleets have grown rapidly and equipped with relevant technologies which increased their catching power. 
It is important to note that foreign fishing fleets came in through the EC/Gambia fishing agreements (1987-96), bilateral agreements with Japanese, Reciprocal Maritime Fishing Agreement with Senegal and through joint ventures with local firms.

Fish production is dominated by artisanal fishermen in The Gambia50 with severe limitations due to sanitary conditions and supply-side constraints including weak infrastructure, limited industrial fishing, weak meso-organisational support, low human resource skills, poor equipments and weak government policy support, among others. Fish catch recorded 39,970 metric tons on 1990 with 26,397 tons (66\%) captured by artisanal fishermen declining to 27,736 tons in 1995 (75\% artisanal fisheries). It rose to 35,762 tons in 2000 dropping marginally to 34,785 tons in 2005 (see Figure 4.3) before increasing to 49,063 tons in 2009 (Mendy, 2009). Artisanal fishermen capture equalled 74.1\% in 2000.

Figure 1: Fish Production

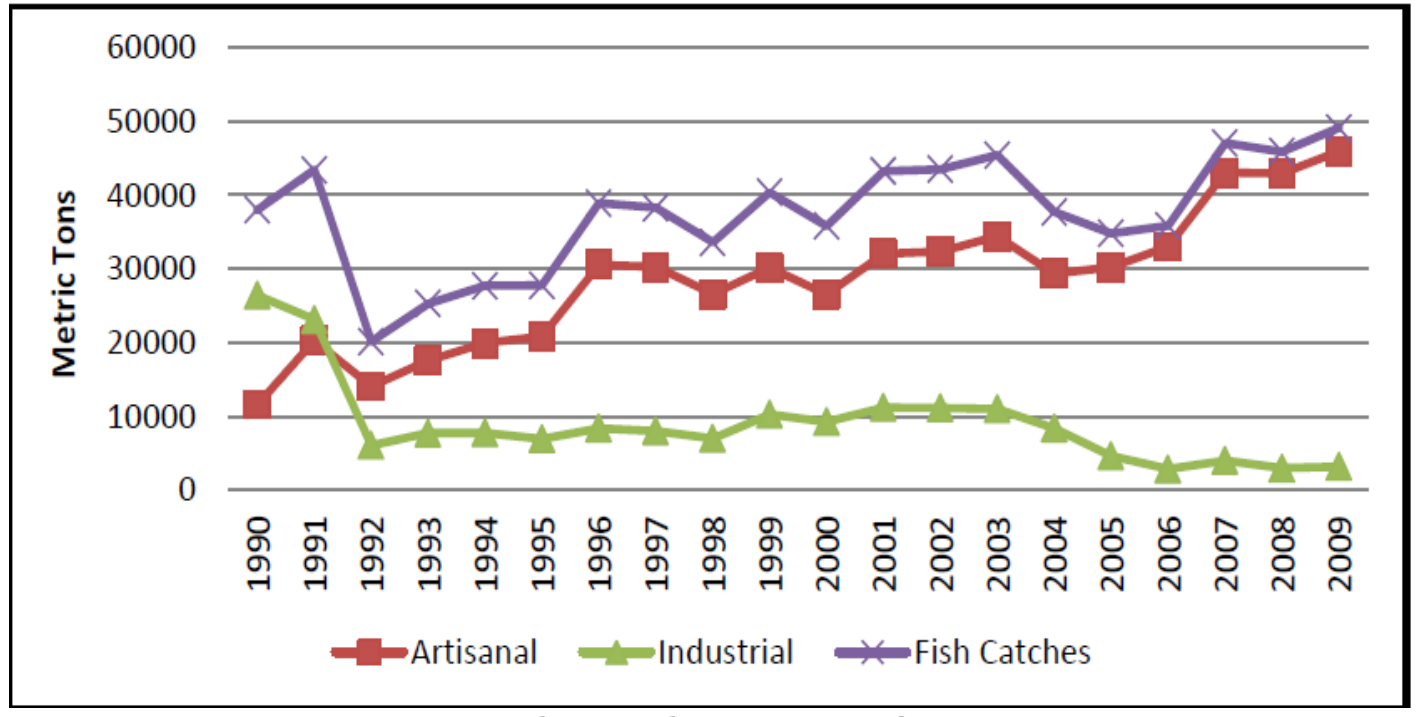

Source: The Gambia Bureau of Statistics

The low export volumes are also associated with Sanitary Phyto-sanitary (SPS) and Hazard Analysis Control Critical Points (HACCP) requirements which artisanal fishermen find difficult to comply with. Export values also show erratic levels from USD2.33 million in 1990 declining to USD1.68 million in 1995. It grew to USD3.35 million in 2000 falling to its trough at USD0.34 million in 2006 (due mainly to fish exporters targeting high value fish coupled with weak artisanal capabilities) before rising further to USD5.93 million in 2010 (GBOS, 2011).

The Gambia does not have a dedicated fish landing site for industrial fisheries52 until 2009, as a result high value fish are transported to neighbouring Senegal and overseas ports where such facilities are available and when processing firms in The Gambia could not absorb all the fresh fish captured. With no EU certified laboratory, fish products are taken to neighbouring Senegal for testing before exports to overseas markets. This is very expensive for many fresh fish exporters. The dried shark fish are exported to Ghana and most West African sub-region while smoked and salted fish are exported to Guinea, Mali and Cameroon. A Shark fin and fish maws are sent to Asia, mainly Hong Kong.

Industrial fish exports target shrimps, sole, snappers, tuna, cuttlefish, octopus, tilapia among others, have plummeted over the years as shown in Table 4.4 and Figure 4.9 due mainly to four key problems (Department of Fisheries, 2009): 
i. The demersal fish stocks are threatened by over-exploitation associated with bilateral fish agreements with Senegal and EU, higher licence fees restricting legal industrial vessels establishments and the increasing illegal fishing

ii. Fish processing is constrained by increasing cost of electricity and finance

iii. The lack of dedicated fishing port for industrial fisheries and poor facilities at landing sites undermine efforts to meet EU SPS standards.

iv. Poor surveillance and an ineffective policing of The Gambia"s EEZ encouraged illegal and irresponsible fishing.

Figure 2: Fish Production and Exports

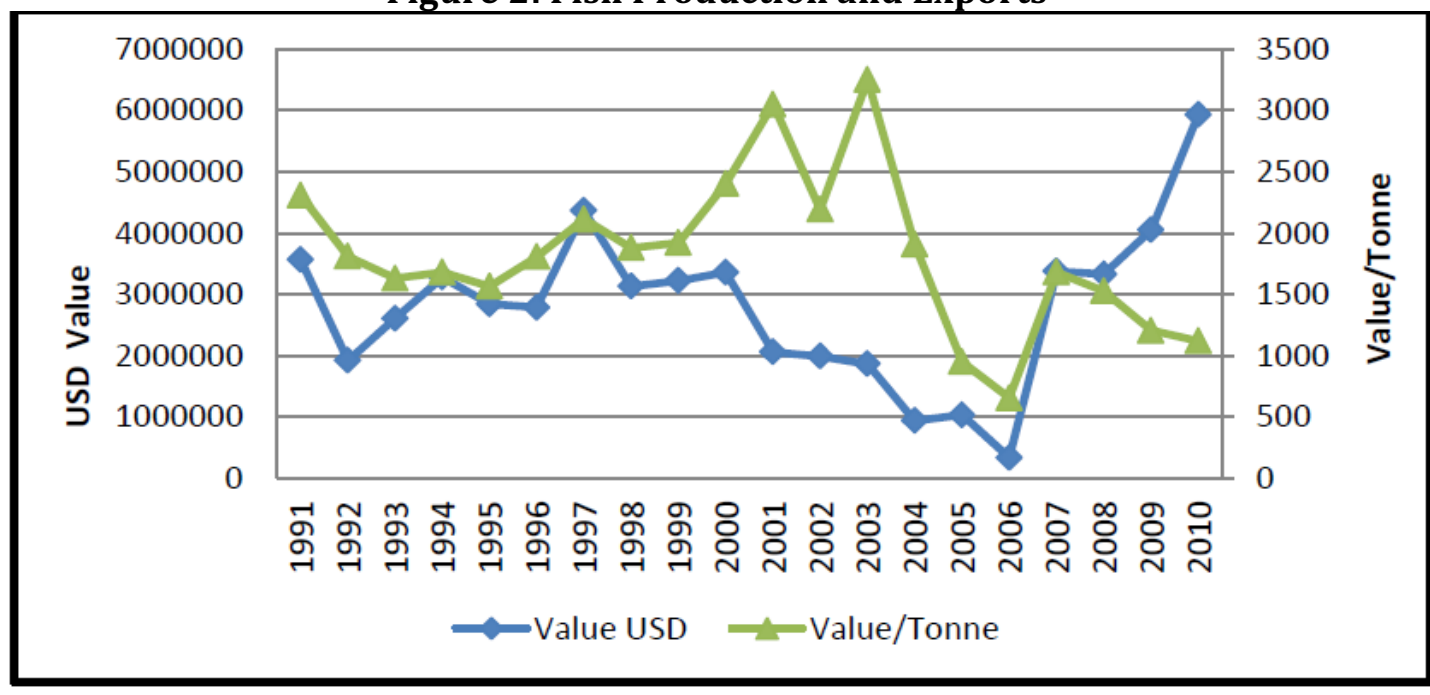

The fishing industry is crucial in the economy of The Gambia, with sector contributing significantly to Gross Domestic Product (GDP), household incomes, food security, tax revenues and employment. Over 200,000 people depend on fish industry for livelihood in The Gambia and remain a major source of animal protein, foreign exchange earnings through exports and fish food security.

Figure 3 : Fishery Supply and Value Chain

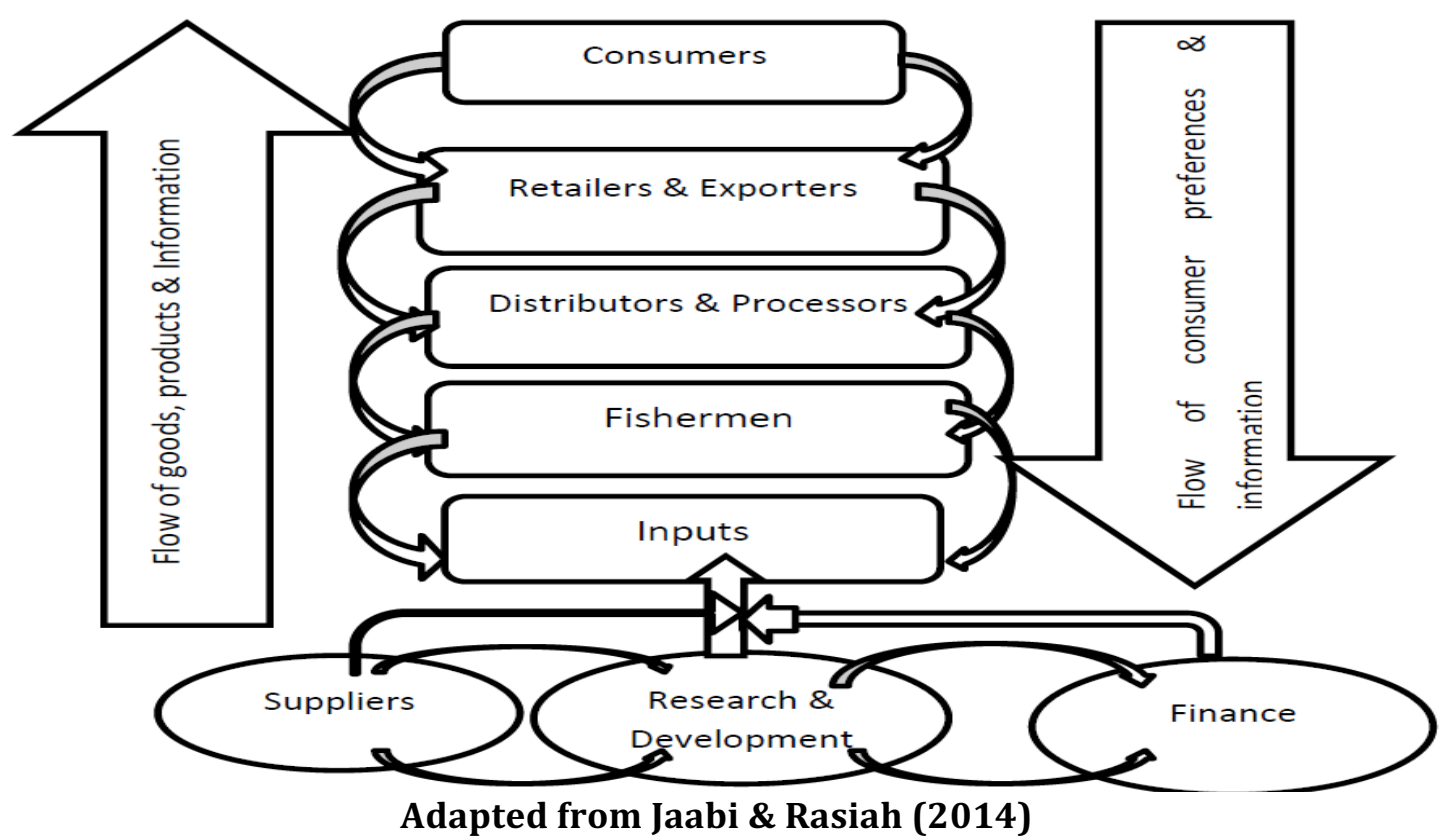


Fish is a highly perishable commodity which, in principle, should have the shortest possible distribution chain with little involvement of intermediaries. However, in reality, the commodity goes through a complex distribution chain from fishermen to the consumer (see Figure 2). The requirement of sanitation and hygiene involved in fish handling are complex and costly, demanding huge access to finance, investment in equipment, human skills, plant layout, cooling systems and other technologies in the entire processing and export supply chain.

As shown in Figure 2 above, financing is needed for R\&D and suppliers of inputs. Steady financing and long-term commitment to R\&D are vital to maintain high standards and hygiene in an effort to produce high quality fish products enabling them to compete effectively in international fish markets.

\section{THEORETICAL CONSIDERATIONS}

In this section, we review past studies in enterprise literature relevant to our study to show the contribution to global literature on SMEs and fish SMEs in particular. Key issues touched here included asymmetric information, demand-side and supply-side constraints, pecking order theory and financial and institutional developments in relation to financial access.

\section{Asymmetric Information}

The Asymmetric Information Theory (AIT) argues that entrepreneurs do have full information of the business income streams and growth opportunities which are not readily available to external financiers - equity investors and creditors. The AIT further argued that smaller and younger firms tend to report higher financing obstacles than larger and older firms (Berger \& Udell, 1998:615-618, 2006 and Becks et al 2004, 2006). Imperfect information and high transaction costs are factors driving the limited access to external formal finance by fish SMEs (Stiglitz \& Weiss, 1981:393). Due to limited access to information on enterprises' income streams by external financiers, it became difficult to appraise loan applications and monitor them efficiently to avoid non-performing loans. The problems of adverse selection and moral hazard are relevant in SME financing in developing countries; as a result, credit is rationed with the possibility that some eligible enterprises are denied credit (Stiglitz \& Weiss, 1981:393-405),

Formal financial information requirements in the form of audited financial statements and business plans are difficult for most SMEs to provide, or even if provided often lack detail, quality and rigor (Berger \& Udell, 2005:1-3 and Michaelas et al, 1999:116). Most fish small enterprises are often not registered with the authorities and do not keep proper record of transactions to facilitate efficient appraisal and monitoring. The situation is further compounded with low collateralised assets to relax information asymmetries (North, 1990; Rocca et al, 2009:12). As a result, external financiers had no option but to limit their financing to vulnerable fish SMEs to control the incidence of non-performing loans. Under this situation, most external financiers either reduce the amount of financing sought, ration or deny access altogether (Stiglitz and Weiss, 1981: 393-394).

The problem of SMEs is more acute in LDCs like The Gambia with high risk profile, volatile rates of return and high incidences start-up failure (Storey, 1994), constrains of capital and skilled human resources to exploit potentials of growth and increase contribution to the economy. This is aggravated by the lack of accurate and reliable information, poor business environment, weak security of transactions and property rights protection problems (Djankov et al, 2007:299-305; Marcel, 1994:2-3; Fafchamps et al, 1995:1-5). 
Studies have shown that business start-ups are generally more informationally opaque constraining their access to external funding (see Beck et al, 2006; Berger and Udell, 1998, 2005 and Stiglitz and Weiss, 1981). Smaller and younger enterprises are less leveraged due to their high information opacity compared with larger and older enterprises. This has inhibited young and small enterprises from accessing external finance as they find it difficult to raise positive cash flows at initial stages of their existence ${ }^{3}$ to service loan interest payments.

\section{Pecking Order Theory (POT)}

The Pecking Order Theory (POT) developed by Myers (1984) argues that enterprises finance their businesses in a hierarchical manner. Myers (1984), Myers \& Majluf (1984) argued that the choice of financing is based on the relative costs of the various financing sources. In this regard, the theory suggests SMEs prefer to choose internal financing sources (personal funds and retained earnings and profits) with relative lesser costs and they will only turn to external finance (debt and equity) when internal funds are inadequate. Therefore, POT showed that enterprises due to opacity problems tend to prefer retained earnings as the lesser information sensitive security (Rocca et al, 2009:5-9; Myers, 1984:576 and Myers \& Majluf, 1984) before external debt and equity capital ${ }^{4}$ in the later stages through to maturity. External debt is also preferred to equity as the latter dilutes ownership with subsequent takeover of the business. As shown in Table 4, small enterprises suffered acute formal financial access instead relies on informal financing sources.

\section{Supply-Side Constraint}

Supply-side constraints are factors that limit the economy's ability to produce or export more goods to global markets. Efforts to address weaknesses in public sector policies and regulatory frameworks, governance, physical and financial infrastructural development, human resource skills and market information will effectively stimulate enterprise increasing access to formal external finance and enhance their global market participation and competitiveness (UNCTAD, 2006) (also see Fulgencio, 2009; Rogers, 2009; Chandra \& Kolavalli, 2006; Lall, 1992:168).

Most development economists have expressed doubts over free markets and global trade benefits to developing SSA economies, in particular its agricultural export sector which is beset with severe supply-side constraints ${ }^{5}$ (UNCTAD, 2006; Fulgencio, 2009:436-441). Inefficiencies at firm level, lack of requisite human and financial resources, weak business environment (Gelb et al, 2007), weak creditor right protection and costly doing business indicators in The Gambia (see Global Economic Forum, 2011) have to a greater extent undermined sustainable financial access and growth of fish SMEs to integrate fully in global markets (Rogers et al, 2009 and Marco, 2004). Accordingly, the ability of economies to address supply-side constraints are able to benefit from increased production, exports, rapid growth, increase employment, value addition and wealth creation (Rasiah, 2007).

\footnotetext{
3 Tarinyeba (2009) among other authors argued that majority of small enterprises opt for other forms of finance particularly informal credit due to high costs, information asymmetric and other constraints in accessing formal finance.

${ }^{4}$ Pinegar \& Wilbricht (1989) showed that financial debt is relatively preferred to equity as a way to raising funds and keeping control of the business.

${ }^{5}$ Despite some concessionary schemes such as the U.S' African Growth and Opportunities Act (AGOA) and the EU's Everything But Arms (EBA) most African economies failed to benefit from these opportunities due to inherent difficulties in accessing finance, low productive capabilities, lacking technologies, non-conformity with product standards and poor connectivity in global trade.
} 
The severe supply-side constraints have resulted to weak SSA industrial sector turning the region into world's least developed economy (Sachs, 2007:827-830, Lall et al, 2005, 1992). Calls for joint corrective action suggest various policy measures including crucial infrastructural development. The adequate supply of infrastructural services (water, telecommunication, power generation capacity, roads, transport, marketing and other enabling institutions) has long been viewed both in policy debate and academic literature (World Bank, 1994) as key pre-requisite for economic development. Consensus has emerged on related empirical literature (World Bank 2006) that under favourable conditions, infrastructural development can be critical in promoting economic growth and equity.

\section{Demand-Side}

Several studies including Becks et al (2005, 2006, 2008), Ayyagari et al (2003) and Fafchamps et al $(1994,1995)$ have argued that capital shortage is a major problem militating against SME growth. However, it is argued that financial institutions do often have excess liquidity to lend than SMEs were willing to borrow (Osei-Assibey, 2011:153). This is blamed on slow industrial growth of SMEs (low institutional developments) and their low absorptive capacities coupled with low capabilities and scale to meet lending requirements of commercial banks (Berger \& Udell, 1998, 2006). As a result, most SMEs in LDCs face difficulties in accessing formal external finance, forcing many to resort to informal financing sources, such as, personal, family, nogovernmental organisations (NGOs) and trade credit to address their financing need.. However, these informal sources are often limited to meet enterprise growth financing requirements.

\section{Financial and Institutional Development}

There is a general consensus among many development economists (Becks, Demirguc-Kunt, Laeven \& Levine 2005; Levine 1997; Demirguc-kunt, 2008; Hussein \& Demetriades, 1996) that financial and institutional developments relieve constrains on enterprise financing obstacles. Accordingly, Levine (1997) argued that financial sector development is an important ingredient as it makes credit available for SME financing, thus enhancing economic growth. Enterprises' lack of access to credit has been identified as one of the factors that not only engender poverty and income inequality (Demirguc-Kunt \& Levine, 2008) but also constrain economic growth and development (see Flessig, 1996). There is general consensus among many researchers on a positive finance-growth nexus and substantial empirical evidence exist that supports this trajectory(Levine, 1997; Hussein \& Demetriades 1996 ; DemirgucKunt 2008) The works of Hussein \& Demetriades (1996) and Levine \& Demirguc-kunt (2008) are indeed robust on financial sector development on enterprise access to finance. However, in SSA where financial sector is shallow and underdeveloped, commercial banks have over the years failed to show much presence in financing small enterprise market. This coupled with market imperfections; institutional weaknesses and poor infrastructure make SME financing a huge challenge in developing African countries. Addressing these issues may require a long -term solution. In the short-run, much collaboration in the form of financial linkages, institutional innovation, adoption of technologies in financial products delivery, addressing collective action problems and crucial role of public sector agencies can be valuable in increasing fish SMEs' financial access.

Institutional development is an important country characteristic that explains enterprises financing patterns. SME financing may be enhanced with enhanced competition, buoyant financial sector and the eradication of restricted policies such as interest rate ceilings and forced sectoral lending (Guiso et al,. 2004). Credit protection and judicial effectiveness in loan recovery makes credit available to SMEs. 


\section{METHODOLOGY}

This section presents methodologies adopted to analyse data on fish enterprise formal financial access. This section covers the sample size, specifications of equations and the dependent and independent variables. The study covered both inductive and deductive approaches on fish SMEs financing. Eviews version 7 is used to test levels of correlation and significance between independent and dependent variables.

\section{Sample Size}

The sample was randomly selected ${ }^{6}$ as there is no comprehensive data on the population of fish enterprises in The Gambia. The sample of 130 respondents is administered on fish SMEs in survey locations from urban areas of Banjul, Bakau and semi-urban and rural Tanji, Gunjur and Kartong in The Gambia from August - December 2015 due to high concentration of fishing activities in these areas. The study focused on fish industry players in the sample including fishermen, distributors, processors, exporters and traders The structured questionnaire served as the main survey instrument coupled with one to one personal interviews conducted employing local languages to ease communication with some illiterate dealers

\section{Specification of Variables}

The main focus of this paper is on the financing sources and constraints faced by fish SMEs at different business phases - start-up and existing businesses. Data on the following variables were collected, processed and analysed as shown below.

\section{Enterprise - level Variables}

The variables used in the analysis include financial access, size, age and export incidence. Eviews version 7 is used to conduct the tests to assess the correlation and levels of significance between dependent and independent variables. We dropped ownership test from the analysis due to the low incidence of foreign firms in the sample.

\section{Access to Finance}

A key question was asked as to whether fish enterprises had attempted to access external finance. Enterprises that do not access external finance reported a number of constraints that limit their access ranging from high interest rates, lack of collateral and guarantors, fear of defaults, among others. Request for finance was then examined against those that were approved and the ones rejected.

Access to Finance (FA) was estimated as:

FA Approved $=1$, FA Rejected $=0$

\section{Source of Finance}

Wide range of financing sources are identified to assess fish SMEs' sources of finance including: personal, support from family and friends, commercial bank, trade credit, microfinance, internal funds, equity, savings and cooperative credits organisations (SACCOs) and government credit schemes. These were assessed at both start-up and existing businesses.

\section{Size Variable}

Size is measured by full time number of employees of fish enterprises. Due to informality of many SMEs in keeping proper records, total assets and total sales may prove difficult hence,

${ }^{6}$ Within the definition of small and medium enterprises of employing 6-100 employees 
making use of number of employees as the best proxy of size. A dummy variable was used to classify size into two categories - small and medium enterprises.

Small Enterprise $\left(\mathrm{S}_{1}=6-20\right.$ employees $)$

Medium Enterprise $\left(S_{2}=21-100\right.$ employees $)$

\subsubsection{Age Variable}

Age is measured as: $A_{i}=$ Number of years of establishment

\subsubsection{Export Incidence}

Fish enterprises were asked whether they participate in fish export market. Many of them do sell to local markets for consumption; some sell to processing and exporting firms while others do export directly to sub-regional and European markets

Export Incidence (EI) was estimated as:

(EI) $1=$ Yes, $\quad$ (EI) $0=$ No

\section{Specifications of Statistical equations}

The section introduced methodologies and data in identifying the financing sources, types and funding structures and economic performance of fish SMEs in The Gambia. Data is analysed using logistic regression to assess the level of correlation and levels of significance of the dependent and independent variables. First, we examine the influence of size on access to finance with Age as a control variable. The second exercise examines size, firm Age and financial access of the fish firms on export incidence (EI) as shown in the following logistic equations.

\section{Specification of Equations:}

Logit: $\mathrm{FA}=\mathrm{C}+\beta_{1}$ Size $+\mathrm{B}_{2}$ EnterpriseAge + Industry_Actors $+\boldsymbol{\mu}$

Logit: $\mathrm{EI}=\mathrm{C}+\beta_{1}$ Size $+\beta_{2}$ EnterpriseAge $+\mathrm{B}_{3}$ FinAccess + Ind._Actors $+\boldsymbol{\mu}$ (2)

Industry Actors include fishermen, distributors and processors

\section{DATA}

The section focuses on the primary data on fishing industry showing the players captured in the sample comprising of fishermen, distributors, processors, exporters and traders as shown in Table 1. Fish small and medium enterprises form 85 (65.4\%) and 45 (34.6\%) across key players as shown in Table 1.

Table 1: Types of Fish SMEs

\begin{tabular}{lcc}
\hline & Small Enterprises & Medium Enterprises \\
\hline Fishermen & $34(40 \%)$ & $18(40 \%)$ \\
Distributors & $9(10.6 \%)$ & $10(22.2 \%)$ \\
Processors & $16(18.8 \%)$ & $10(22.2 \%)$ \\
Exporters & $0(0.0 \%)$ & $2(4.4 \%)$ \\
Traders & $26(30.6 \%)$ & $5(11.1 \%)$ \\
\hline Total & $85(100 \%)$ & $45(100 \%)$ \\
\hline
\end{tabular}

Fishermen form the highest proportion of the sample in both categories followed by traders and processors among small enterprise and processors and distributors under medium 
enterprises. Exporters recorded the least among both small and medium enterprises due mainly to stringent quality standard requirements on fresh fish exports to EU markets.

\section{Financial environment}

The section examines sources and constraints of finance face by fish SMEs in The Gambia. The analysis in this section is interpretative. Further analysis of the financial variables against performance is assessed in the next section.

\section{Sources of finance}

The sources of finance are analysed at two different periods - start-up and working capital financing of existing fish enterprises showing different financing structures.

\section{Start-ups}

Fish small enterprise start-up financing sources are dominated by personal and family funding with $74.1 \%$ mainly among small fish enterprises. However, informal financing declined significantly for medium enterprises due mainly to more visibility, increase asset size and formality. Government credit schemes financing is lower among small enterprises relative to medium enterprises as many small enterprises are not registered with the authorities. Bank financing was the least among small enterprises due probably to high asymmetric information, collateral constraints and reputation at start-up as highlighted in the literature.

Government project financing of fish SMEs in collaboration with international development agencies such as The African Development Bank (AfDB), International Fund for Agricultural Development (IFAD), UNIDO and The Food and Agriculture Organisation (FAO) are prominent at start-up financing but targeted largely medium enterprises. Many small enterprises rely mainly on personal, family and trade credit financing at start-up compared with medium enterprises on various financing sources - bank, microfinance, SACCOs and government financing as shown in Table 2. The funds managed by donor projects are retailed to fish SMEs through financial institutions licensed by The Central Bank of The Gambia.

Table 2: Start-up sources of finance of fish SMES in The Gambia, 2015

\begin{tabular}{|c|c|c|}
\hline & Small Enterprises & Medium Enterprises \\
\hline Personal & $46(54.1 \%)$ & $7(12.7 \%)$ \\
\hline Family & $17(20 \%)$ & $0(0 \%)$ \\
\hline Bank & $0(0 \%)$ & $3(5.5 \%)$ \\
\hline Trade credit & $9(10.6 \%)$ & $10(18.2 \%)$ \\
\hline Microfinance & $0(0 \%)$ & $14(25.5 \%)$ \\
\hline Equity & $1(1.2 \%)$ & $5(9.1 \%)$ \\
\hline SACCOs & $7(8.2 \%)$ & $6(10.9 \%)$ \\
\hline Government credit schemes & $5(5.9 \%)$ & $10(18.2 \%)$ \\
\hline Total & $85(100 \%)$ & $55(100 \%)$ \\
\hline
\end{tabular}

\section{Working Capital Financing}

Table 3 shows working capital financing sources with formal financing skewed away from informal personal and family financing sources to more formal external financing. Informal financing declined from $74.1 \%$ informal financing sources to $33.8 \%$ at working capital category. Formal financing became prominent at working capital financing associated with more visibility, track record and accumulation of collaterised assets. It is interesting to note that government schemes financing has reduced from $18.2 \%$ at start-up to just $13.6 \%$ at working capital among medium enterprises suggesting that more of government fish SME 
financing target enterprises at start-up. It also declined among small enterprise working capital financing at $4.6 \%$ from $5.9 \%$ at start-up. However, external financing is still a problem in the fisheries industry with many small enterprises opting for retained earnings and informal credits due to difficulties of accessing formal financial credits in line with the works of Djankov et al (2007); Bigsten et al (2003), Chittenden et al (1996; Fafchamps et al, 1994, 1995) .

Table 3: Working capital financing sources of fish SMES

\begin{tabular}{lll}
\hline & Small Enterprises & Medium Enterprises \\
\hline Personal & $28(32.6 \%)$ & $0(0.0 \%)$ \\
Family & $1(1.2 \%)$ & $0(0.0 \%)$ \\
Bank & $0(0.0 \%)$ & $10(22.7 \%)$ \\
Trade credit & $9(10.5 \%)$ & $0(0.0 \%)$ \\
Microfinance & $3(3.5 \%)$ & $16(36.4 \%)$ \\
Internal funds & $39(45.3 \%)$ & $2(4.5 \%)$ \\
SACCOs & $2(2.3 \%)$ & $10(22.7 \%)$ \\
Government credit schemes & $4(4.6 \%)$ & $6(13.6 \%)$ \\
\hline \multicolumn{2}{l}{ Total } & $\mathbf{8 6 ( 1 0 0 \% )}$ \\
\hline \multicolumn{2}{c}{ Source: Author's Survey (2015) }
\end{tabular}

The findings show that external financing is bias against smaller and younger enterprises with larger and older firms being prominent in bank and microfinance lending as corroborated in SME financing literature(Rocca et al, 2009; Michaelas et al, 1999; Beck, 2006; fafchamps et al 1995; Daniel 1994; Bigsten et al 2003).

\section{Financing Constraints}

Figure 4 shows financing constraints of fish SMEs in The Gambia. From the sample of 130 respondents, $59.2 \%$ reported access to formal external finance difficulties. It is noted that financing constraints existed only among small fish enterprises with medium enterprises accessing one form of external financing or the other.

Figure 4: Fish Enterprises Constraints To Financial Access, 2015

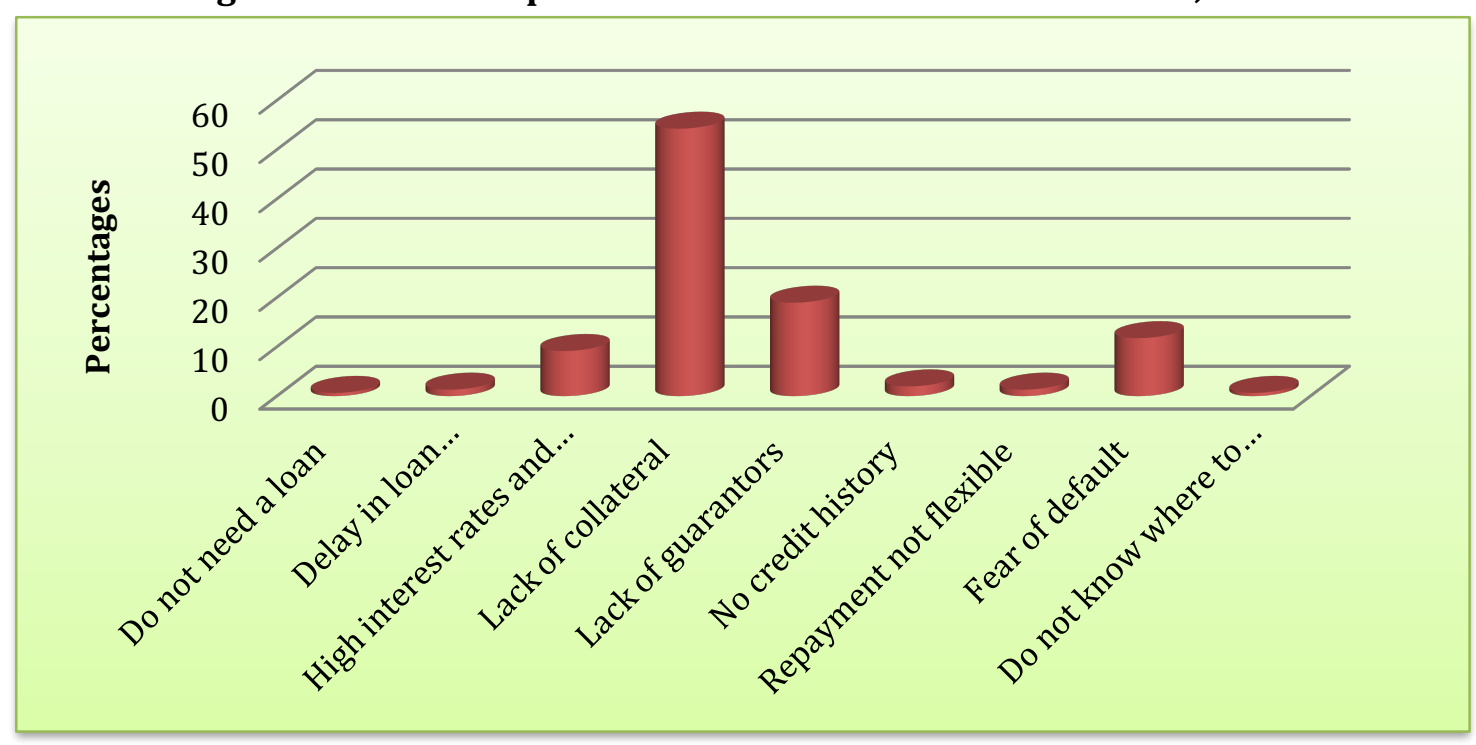

Source: Author's Survey (2015)

Figure 4 show constraints in accessing external finance, prominent among the obstacles are lack of collateral, lack of guarantors, fear of loan default and high loan interest. Lack of 
collateral constitutes the highest at $55.8 \%$ followed by lack of guarantors $(14.3 \%)$, fear of default (14.28\%) and high interest charges (9.1\%).

\section{STATISTICAL RELATIONSHIPS}

This section attempts to establish analytically the relationship between dependent variables of financial access and export incidence with host of independent variables. First, we examine with relationship between financial access and size with enterprise age as control variable. Second, we examine enterprise age, size and financial access on export incidence of fish enterprises.

\section{Financial Access, Enterprise Size and Age}

In this section we examine the relationship between financial access and enterprise size with firm Age as control variable. The model fit (LR-stats) for the Logit estimation is positive and significant at 1\%. The relationship between financial access and enterprise size is also positive and significant at $1 \%$ suggesting that size is relevant in accessing formal external finance in the fisheries industry in The Gambia.

Table 4: Access to Finance and Firm Size, Age

Logit: FinAccess $=C+\beta_{1}$ Size $+\beta_{2}$ Age + Industry_Actors $+\mu$

\begin{tabular}{llll}
\hline & Coefficient & \multicolumn{1}{c}{ Std Error } & \multicolumn{1}{c}{$\boldsymbol{Z}$} \\
\hline Constant & $-4.3204^{* * *}$ & 0.5163 & -5.0315 \\
Size_EM & $0.3680^{* * *}$ & 0.0724 & 5.0808 \\
Age & $0.235^{* *}$ & 0.045 & 1.995 \\
Fishermen & & & \\
Distributors & & & \\
Processors & & & \\
LR- Stats & $104.7899^{* * *}$ & & \\
N & 130 & & \\
\hline
\end{tabular}

Source: Author's Survey 2011. Note ${ }^{* * *}$ and $*$ refer to statistical significance at $1 \%$ and $5 \%$

Enterprise Age also reported a positive and significant relationship with financial access suggesting that enterprise finance grows with age in line with the literature (see Rocca et al, 2009, 2011; Michaelas et al, 1999; Berger and Udell, 1998, 2006). The results show that the larger the enterprise, the greater the probability of accessing formal external financial credit. Despite government credit schemes of providing special assistance to fish SMEs, small-size and young enterprises continue to face constraints in accessing external financial debt.

\section{Export Incidence and Financial Access}

The model fit of logit regression show export incidence and financial access statistically positive and significant suggesting access to formal finance matters in participating in export market. 
Table 5: Export Incidence and Firm Age, Size and Financial Access

Logit $\mathrm{EI}=\mathrm{C}+\beta_{1}$ Size $+\beta_{2}$ FirmAge $+\mathrm{B}_{3}$ FinAccess $+\boldsymbol{\mu}$

\begin{tabular}{llll}
\hline & Coefficient & Standard Error & \multicolumn{1}{c}{ Z Score } \\
\hline C & $-1.374^{* * *}$ & 0.3688 & -5.2318 \\
Enterprise_Age & $0.027^{*}$ & 0.0044 & 1.8363 \\
Size_EM & $0.088^{* * *}$ & 0.0354 & 4.9586 \\
FinAccess & $0.1897^{* * *}$ & 0.7643 & 2.8053 \\
Fishermen & & & \\
Distributors & & & \\
Processors & & \\
LR Statistics & $102.7815^{* * *}$ & & \\
$\mathrm{~N}$ & 130 & & \\
\hline
\end{tabular}

Source: Author's survey (2011). Note ${ }^{* *}$ and ${ }^{*}$ refer to statistical significance at $1 \%$ and $10 \%$

Fish being perishable agricultural commodity requires greater financing possibilities in terms of maintaining fish quality, sanitary conditions, acquire equipments and plants at factory level. Enterprise age and size also reported positive and significant relationship to export incidence manifesting size and age matter in fish export market participation. Those that cannot export directly sell to local markets and processing and exporting enterprises to supplement their export tonnage target for overseas markets.

From Table 5, the relationship between Export Incidence and Financial Access is statistically positive and significant meaning participating in export market depends on fish enterprises' access to external finance. The Gambia's fisheries sector is dominated by artisanal fisheries with very few industrial enterprises coupled with the lacking vital public support, capabilities at enterprise level constrain the industry's participation in export market. With these weaknesses, age, size and financial access undoubtedly become statistically positive and significant relationship with export incidence.

\section{IMPACT OF FISH CATCHES AND EXPORTS}

Figure 3 shows the value dropping consistently from 1997 through to 2006 before increasing to 2010 associated with targeting fish pieces with higher value prices in global markets and difficulties in meeting overseas sanitary and quality standards. The catches also show similar inconsistent trend due mainly to the dominant artisanal fisheries in the sector with considerable weakness to capture fish in large quantities and the capabilities of exporting to sophisticated markets. The lack of finance and institutional capabilities have limited fish enterprises productivity in terms of fish production and exports as shown in Figure 5.

Fish export is the second largest agricultural export commodity after groundnuts constituting $15 \%$ of merchandise export earnings (Central Bank of The Gambia, 2011). Fish exports were high at USD4.36 million in 2000 dropping considerably thereafter through to its lowest of USD0.33 million in 2006 due mainly to weak export volumes, explained by fish exporting enterprises targeting high valued fish in overseas markets. It rose again from USD3.37 million in 2007 through to USD5.93 million in 2010. 


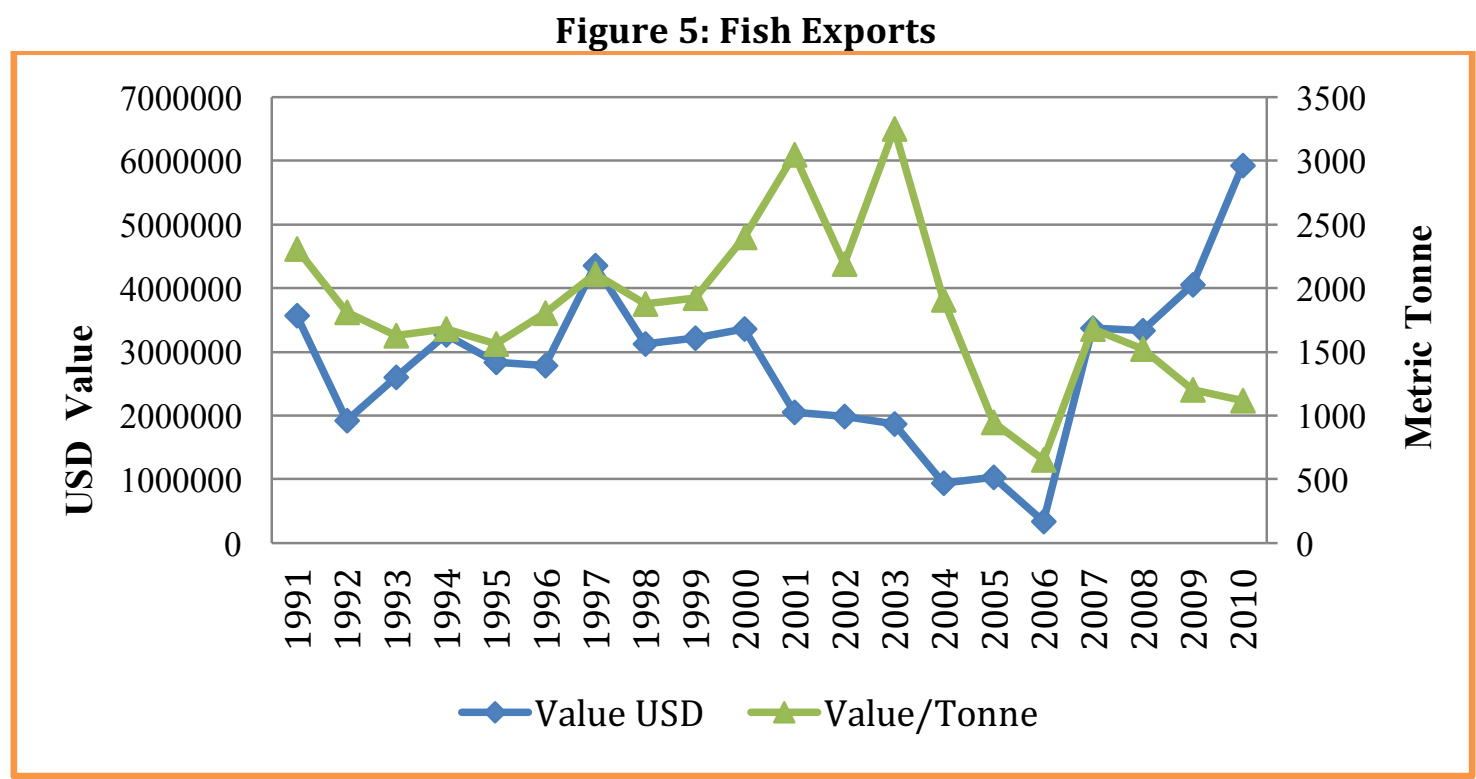

Source: The Gambia Bureau of Statistics, (2011), Department of Fisheries, (2011)

\section{CONCLUSION}

We examined enterprise financing in the fisheries industry of The Gambia with empirical data. The results show that despite government support, enterprise size matters in access to external financial credit. Small fish enterprises are mainly financed by microfinance, SACCOs, government projects, personal and family finances with exclusively marginal financing from commercial banks due mainly to information asymmetries and collateral issues. The findings manifest small enterprise financing constraints reflecting a positive correlation between access to finance and enterprise size. With acute financing constraints, many fish SMEs do conveniently access trade credit (see Fafchamps 1994, 1995; Bigsten et al, 2003; Djankov et al, 2007; Mead and Liedholm, 1998), leasing of equipments and support from overseas importers in pre-financing arrangements.

Due mainly to high risk profile of small enterprises and by extension private sector coupled with adverse business environment, asymmetric information and state of property rights protection, public sector tend to dominate formal bank financing. With agricultural sector face with high risk, formal bank financing remains quite low at its highest of $4.1 \%$ of total private sector financing in The Gambia despite being the food basket, majority share of jobs and its export potentials. The business infrastructural constraints go to undermine fish SMEs access to external finance, hence limit their performance, growth and contributions to the economies. To address this situation requires a medium to long-term measures. However, in the shortrun, the banking sector must strategise using innovative lending methodologies to finance this vital sector in the presence of adverse business environment.

The role of government in fish SME financial access is crucial. However, despite its interventions with credit schemes targeted at fish SMEs, this has not reduce their acute lack of external finance as majority of fish enterprises reported access to external finance as a major obstacle. Therefore size matters in external financial access.

Despite its importance in the economy in terms of employment, household income for fishermen and processors, export revenue, rates and taxes, formal financing to the fisheries industry is miniscule retarding growth and development (paradox). Efforts to address constraints in fish enterprise financial access, build capabilities, acquire right equipments, upward and downward linkages in the sector are urgently required if the industry is to contribute immensely to the economy of The Gambia. 


\section{References}

Ayyagari, M., Beck, T., \& Demirguc-Kunt, A. (2003). Small and Medium Enterprises across the Globe: A new Database. World Bank Policy Working Paper 3127.

Ayyagari, M., Demirguc-Kunt, A., \& Maksimovic, A. M. (2005). How important are financing constraints? The role of finance in the business environment: World Bank Mimeo.

Beck, T. (2007).Financing constraints of SMEs in developing countries: Evidence, determinants and solutions.Journal of International Money Finance, 31(2), pp. 401 - 441.

Beck, T., \& Demirguc-Kunt, A. (2006). Small and medium-size enterprises: Access to finance as a growth constraint. Journal of Banking and Finance, 30, 2931-2943.

Beck, T., \& Demirguc-Kunt, A. (2008). Access to finance: An Unfinished Agenda. World Bank Economic Review, 22(3).

Beck, T., Demirguc-Kunt, A., Laeven, L., \& Levine, R. (2004a). Finance, firm size and growth: World Bank Mimeo.

Beck, T., Demirguc-Kunt, A., \& Maksimovic, V. (2004).The determinants of financing obstacles.World Bank Policy Research Working Paper 3204.

Beck, T., Demirguc-Kunt, A., \& Maksimovic, V. (2005). Financial and Legal Constraints of Firm Growth: Does Firm Size Matter? Finance, 60, 137-177.

Beck, T., Demirguc-Kunt, A., \& Paria, M. S. M. (2008). Banking financing for SMEs around the world: Drivers, Obstacles, Business Models and Lending Practices. World Bank Policy Research Working Paper 4785.

Berger, A., \& Black, L. (2011).Bank Size, Lending Technologies and Small Business Finance.Banking and Finance, $35,724-735$.

Berger, A. N., \& Udell, G. F. (2005).Conceptual Framework for Financing of Small and Medium Enterprises. Washington D C: World Bank.

Bigsten, A. (2003). Credit Constraints in Manufacturing Enterprises in Africa.Journal of African Economics, 12(104).

Demirguc-Kunt, A., Love, I., \& Maksimovic, V. (2006).Business environment and the incorporation decisions.Journal of Banking and Finance.

Diamond, D. (1984).Financial intermediation and delegated monitoring.Review of Economic Studies, 51(3), 393414.

Djankov, S., McLiesh, C., \& Shleifer, A. (2007).Private Credit in 129 Countries.Journal of Financial Economics, 84(299).

Fatoki, O. O., \& Smit, V. A. (2011). Constraints to credit access by new SMEs in South Africa: A supply-side analysis. African Journal of Business Management, 5(4), 1413 - 1425.

Guiso, L., Sapienza, P., \& Zingales, L. (2004). Does Local Financial Development Matter?*. Quarterly Journal of Economics, 119(3), 929-969.

Levine, R. (1997). Financial development and economic growth: Views and Agenda. Economic Literature, 35, 688726.

Liedholm, C., \& Mead, D. C. (1999).Small Enterprises and Economic Development.The dynamics of Micro and Small Enterprises. London.

Love. (2003). Financial development and financing constraints: International Evidence from the structural model. Review of financial studies, 16(3), 765-791.

Michaelas, N., Chittenden, F., \& Poutziouris, P. (1999). Financial Policy and Capital Structure Choice of UK SMEs: Empirical Evidence from Company Panel Data, Journal of Small Business Economics, 12(2), 113-130.

Myers, (1984).The capital structure puzzle.Journal of Finance, 57(3), 575-592.

Myers, S., \& Majluf, N. (1984). Corporate finance and investment decision when firms have information that investors do not have. Journal of Financial Economics, 13(2), 187-221.

Petersen, M., \& Rajan, R. (1994). The benefits of lending relationships: evidence from small business data. Journal of Finance, 49(1), 3-37.

Rajan, R., \& Zingales, L. (1995). What do we know about capital structure? Some evidence from international data.Journal of Finance, 50(5), 1421-1460. 
Robb, A. M. (2002). Small business financing: Differences between young and old firms. Journal of Entrepreneurial Finance and Business Ventures, 7, 45-65.

Rocca, M. L., Rocca, T. L., \& Cariola, A. (2009). Small Business Financing: Financial preferences throughout the life cycle of a firm. University of Calabria, Italy.

Rogers, M., \& Pontius, B. (2009).Uganda's Supply-Side Constraints and Performance of Exportable Products in the Global Market. Makerere University Business School, Uganda. Kampala.

Schiffer, M., \& Weder, B. (2001). Firm size and the business environment: Worldwide survey results. IFC Discussion Paper, Washington D C, 43.

Seuwaegen,\& Goedhuys. (2002). Growth of firms in developing countries: Evidence from Cote D'Ivoire. Development Economics, 68, 117-135.

Stighlitz, J., \& Weiss, A. (1981).Credit Rationing in Markets with imperfect Information.The American Economic Review, 71(393).

UNCTAD.(2006). Supply-Side Constraints on the trade performance of African Countries Trade Capacity Building Background Paper. 